\title{
Local perceptions of interactions between elephants and Borassus aethiopum Mart. (Arecaceae) in the Pendjari National Park in Benin
}

Juliano S. H. HOUNDONOUGBO ${ }^{1}$ Valère K. SALAKO ${ }^{1}$

Rodrigue IDOHOU ${ }^{1}$

Fortuné A. AzIHOU ${ }^{1,2}$

Achille E. AssogBadjo ${ }^{1,2}$

Romain GLÈLÈ KAKAĨ ${ }^{1}$

${ }^{1}$ Université d'Abomey-Calavi Faculté des Sciences Agronomiques Laboratoire de Biomathématiques et d'Estimations Forestières 04 BP 1525, Cotonou Bénin

2 Université d'Abomey-Calavi Faculté des Sciences Agronomiques Laboratoire d'Écologie Appliquée 03 BP 2819, Cotonou Bénin

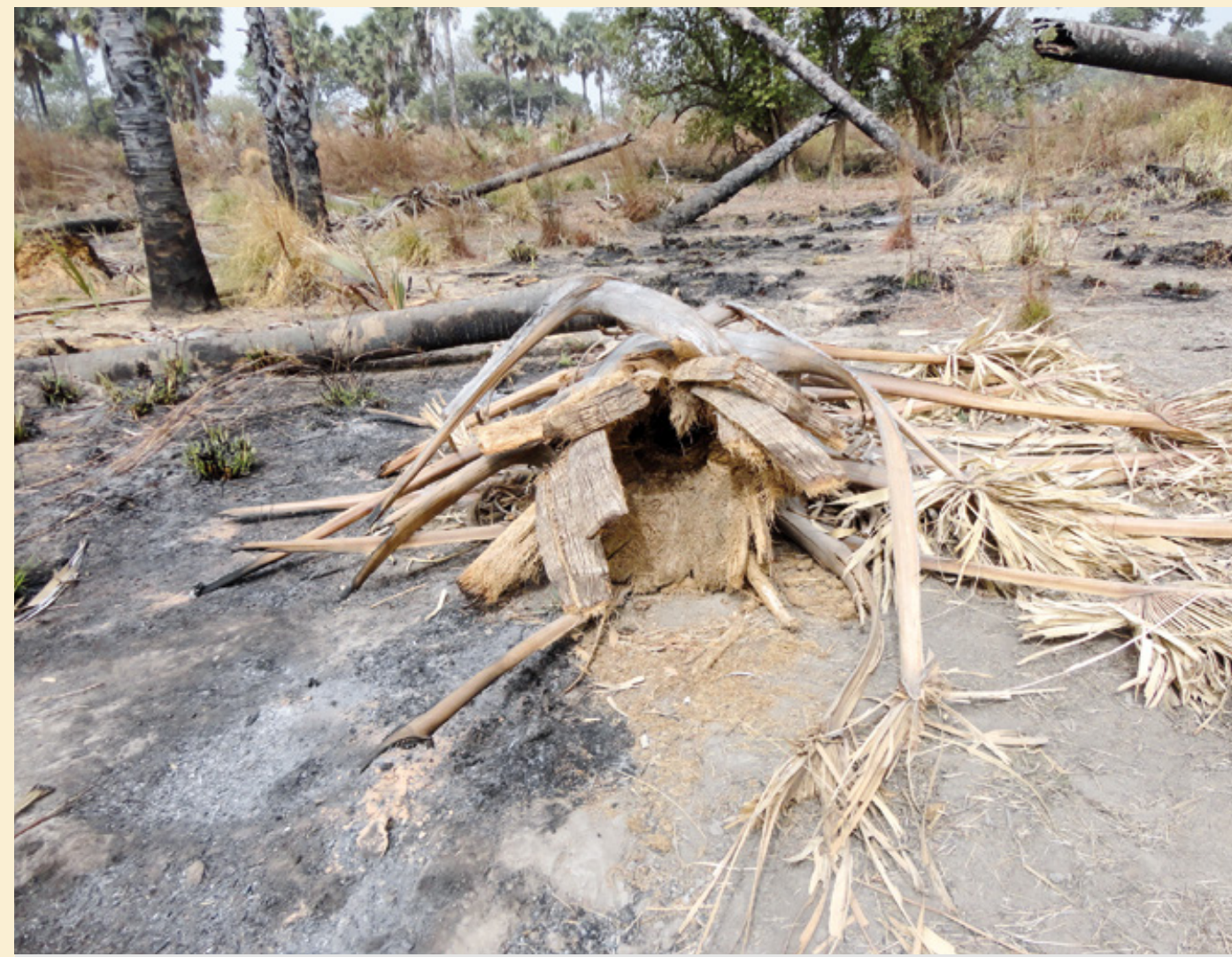

Photo 1.

Elephants cause damage to Borassus aethiopum for food and subsistence.

Photo J. S. H. Houndonougbo. 


\section{RÉSUMÉ}

\section{PERCEPTIONS LOCALES DES INTERACTIONS ENTRE LES ÉLÉPHANTS ET LE PALMIER BORASSUS AETHIOPUM MART. (ARECACEAE) DANS LE PARC NATIONAL DE LA PENDJARI AU BÉNIN}

Différents constats indiquent que l'impact des éléphants sur la végétation ligneuse dans les aires protégées devient dramatique. Une gestion durable de la biodiversité dans ces écosystèmes nécessite le respect d'un bon équilibre entre populations d'éléphants et peuplements d'essences ligneuses. Pour y parvenir, les perceptions des habitants et des gestionnaires des aires protégées peuvent éclairer fort utilement les résultats des suivis et inventaires écologiques classiques. La présente étude visait à évaluer les perceptions des gestionnaires et des populations locales quant aux causes, dégâts et conséquences de la pression exercée par les éléphants sur le palmier rônier Borassus aethiopum, actuellement en déclin, ainsi qu'aux options de gestion de cette pression. L'étude a été réalisée dans le Parc National de la Pendjari, une des composantes du complexe de réserves transfrontalières du W-Arly-Pendjari en Afrique de l'Ouest. Des entretiens semi-structurés ont été menés avec 53 personnes issues de trois catégories socioprofessionnelles différentes : administrateurs, écogardes et chasseurs professionnels locaux. La fréquence relative des citations et la corrélation de Pearson nous ont permis d'évaluer, respectivement, le consensus et les concordances des perceptions. Les personnes enquêtées ont fait part d'une forte augmentation du nombre d'éléphants dans la Pendjari, attribuée à une migration significative d'éléphants en provenance des parcs transfrontaliers où la pression du braconnage serait élevée. Cela conduit à une forte pression sur les essences ligneuses, dont $B$. aethiopum. Malgré les différences professionnelles, des opinions consensuelles et concordantes ont été constatées entre les administrateurs, écogardes et chasseurs professionnels locaux à l'égard des interactions entre éléphants et $B$. aethiopum. Pour limiter la migration des éléphants, une approche régionale est proposée visant à protéger les populations d'éléphants (réduction du braconnage) du complexe W-Arly-Pendjari et des réserves voisines.

Mots-clés : palmier rônier, Borassus aethiopum, éléphant, pression, gestionnaires de réserve, savane, Afrique de l'Ouest.

\section{ABSTRACT}

\section{LOCAL PERCEPTIONS OF INTERACTIONS BETWEEN ELEPHANTS AND BORASSUS AETHIOPUM MART. (ARECACEAE) IN THE PENDJARI NATIONAL PARK IN BENIN}

Elephants are reported to have a dramatic impact on woody vegetation in protected areas. Careful control of elephant and wood species populations is therefore crucial to successful biodiversity management in such ecosystems. The perceptions of local people and protected areas managers could very usefully supplement classic ecological surveys and monitoring to achieve this goal. This study assessed the perceptions of managers and local people regarding the causes, damage, consequences and management options of elephant pressure on the declining dioecious palm Borassus aethiopum. The study was conducted in the Pendjari National Park, which is part of the W-Arly-Pendjari transboundary complex of reserves in West Africa. Semi-structured interviews were conducted with 53 respondents belonging to three socio-professional categories: administrators, ecoguards and local professional hunters. Relative frequency of citation and the Pearson correlation were used to assess the consensus and concordance of their perceptions, respectively. The respondents reported a steep increase in the number of elephants in the Pendjari National Park, which they attributed to significant elephant migration from transboundary parks where poaching pressure was perceived as high. This has resulted in high pressure on tree species including $B$. aethiopum. Despite differences in professional outlook, consensual and concordant opinions were noted among administrators, ecoguards and local professional hunters on the relationship between $B$. aethiopum and elephants. A regional approach aiming to protect the elephant population (low poaching) in the W-Arly-Pendjari complex and other neighbouring reserves was suggested in order to limit elephant migration.

Keywords: African fan palm, elephant, pressure, reserve managers, savannah, West Africa.

\section{J. S. H. Houndonougbo, V. K. Salako, R. IDOHOU, F. A. Azihou, A. E. Assogbadjo, R. GLÈlÈ KAKAï}

\section{PERCEPCIONES LOCALES DE LAS INTERACCIONES ENTRE ELEFANTES Y LA PALMA BORASSUS AETHIOPUM MART. (ARECACEAE) EN EL PARQUE NACIONAL DE PENDJARI EN BENÍN}

Distintas observaciones indican que el impacto de los elefantes en la vegetación leñosa de áreas protegidas se está volviendo dramático. Un adecuado manejo de la biodiversidad en estos ecosistemas requiere mantener un buen equilibrio entre la población de elefantes y las masas de especies leñosas. Para lograrlo, podría ser muy útil completar las tradicionales encuestas y acciones de seguimiento ecológico con las percepciones de lugareños y gestores de áreas protegidas. Este estudio evaluó las percepciones de gestores y lugareños sobre las causas, daños y consecuencias de la presión de los elefantes en el declive de la palma de abanico africana Borassus aethiopum y las opciones de manejo. El estudio se llevó a cabo en el Parque Nacional de Pendjari, que forma parte del complejo de parques transfronterizo W-Arly-Pendjari en África Occidental. Se realizaron entrevistas semiestructuradas a 53 personas pertenecientes a tres categorías socioprofesionales: administradores, ecoguardas y cazadores profesionales. La frecuencia relativa de citación y el coeficiente de correlación de Pearson nos permitieron evaluar, respectivamente, el consenso y la concordancia de sus percepciones. Los encuestados señalaron un fuerte aumento del número de elefantes en el parque de Pendjari que atribuyeron a una significativa migración de elefantes de los parques transfronterizos en los que habría una alta presión del furtivismo. Esto ha provocado una fuerte presión sobre las especies leñosas como B. aethiopum. A pesar de las diferencias de las percepciones según las categorías profesionales, se observaron opiniones de consenso y concordantes entre administradores, ecoguardas y cazadores profesionales sobre las interacciones entre elefantes y $B$. aethiopum. Para limitar la migración de los elefantes, se propuso un enfoque regional para proteger las poblaciones de elefantes (reducción del furtivismo) del complejo W-Arly-Pendjari y las reservas vecinas.

Palabras clave: palma de abanico africana, Borassus aethiopum, elefante, presión, gestores de reservas, sabana, África Occidental. 


\section{Introduction}

Elephants can have a dramatic impact on their habitat. The "elephant problem" in which high densities of elephant (Loxodonta africana Blumenbach) in African savannas have severe impacts on woody vegetation, has been a concern for several decades (Barnes, 1983). Elephant abundance has conservation implications because of their impact on other species, especially when confined and/or occurring at relatively high densities (Western and Maitumo, 2004). Under such conditions, their foraging and feeding habits may reduce tree densities and transform forests and intact woodlands into mixed woodlands and even grasslands (Mosugelo et al., 2002). These changes in vegetation caused by elephants, often in combination with other factors such as fire, incur elevated mortality of mature trees and suppress recruitment and regeneration. The problem was also emphasized by compression of elephant populations into parks in response to expanding human settlement (Lewis, 1986). Faced with severe impacts, and their concomitant implications for biodiversity loss (Fritz et al., 2002), managers of reserves seek to make informed decisions regarding possible control of elephant populations (Whyte et al., 1999).

The validity of concerns about increases in elephant populations, resistance to culling, challenges that elephant "damage" has been ill-defined, and debate about the savanna functioning (Gillson and Lindsay, 2003), requires a greater understanding of the impact of elephant on vegetation. Impact of elephants on woody vegetation has led to concern about possible extirpation of plant species which persistence depends on forest or woodland habitat (Botes et al., 2006). For example, elephant damage has resulted in dramatic changes in the population structure of Adansonia digitata L. (Kassa et al., 2014), Acacia tortilis Hayne (Mwalyosi, 1985), and Borassus aethiopum Mart (Salako et al., 2016). Besides, a study by Morrison et al. (2016) has particularly highlighted the strong insights into dramatic recent declines of individual trees over the 5 years period in Serengeti National Park in northern Tanzania.

Most studies on elephant-plant interactions within protected areas have focused on ground or remote sensing data (Fullman et al., 2014) with less examples of local ecological knowledge assessment. Studies using local ecological knowledge assessment have been often limited to cases of crop raiding by elephants outside protected areas (Karimi, 2009). The most common source of information about the condition of protected areas is the personal experience of "on-ground" managers, i.e., those individuals responsible for the day-to-day management decisions and activities within a protected area (Cook and Hockings, 2011). Increasingly, personal knowledge in the form of Local Ecological Knowledge (LEK) is being considered particularly useful for environmental management decisions (Anadón et al., 2009). Therefore, the LEK of "on-ground" managers may provide a rich and readily available source of information for protected area management agencies to supplement existing data. Given the shortage of scientific information in protected areas (Cook et al., 2010), the experience of managers could be an important substitute for, or complement to the empirical scientific data to guide management decisions. Prior ethnoecological studies advocated an integration of local perceptions and ecological studies to improve ecological impact assessment, and develop better plans for sustainable resource management (Fraser et al., 2006). Indeed, these works have demonstrated how demographic factors such as professional specialization can shape local ecological knowledge and perceptions in resources management (Müller-Schwarze, 2006). As such, an improved understanding of how people appreciate these impacts on tree species can shed light on the appropriate strategies to conserve them. Ethnoecological survey could also provide rapidly useful information regarding relationship between plants and animals before detailed on-field study.

Borassus aethiopum (African fan palm) is a slow growing and dioecious palm species of West African savannas (Barot and Gignoux, 1999). It is a multipurpose tree species which provides local people with several ecosystem services (food, medicine, stipe for construction, shelter, material for craft, etc.) (Mollet et al., 2000). This array of usages added to overharvesting of the fruits and stipe of the species have resulted in unprecedented anthropogenic pressures on the species, causing a steep decrease of its population countrywide (Adomou et al., 2011; Agyarko et al., 2014; Mollet et al., 2000). Because of this pressure, B. aethiopum is rated Vulnerable on the Benin red list of threatened species (Adomou et al., 2011). Protected areas, particularly national parks are thought to be integral for its conservation in Benin because of the very limited anthropogenic pressure in these areas (Adomou et al., 2011). However, B. aethiopum provides important food resources for elephants and as such undergoes important damage in the Pendjari National Park (PNP) in Benin (Salako et al., 2016) as elsewhere in Africa (Giffard, 1967; Arbonnier, 2004). Elephants cause damage to the trees by uprooting them with their faces, breaking them with their tusks, extracting the palm heart as well as its fruits, thus posing a serious conservation issue (Salako et al., 2016). There has been an increasing effort to describe the impact of elephants on woody vegetation (Lombard et al., 2001). These works have led to concern about possible extirpation of plant species in the face of elephants' pressures as certain parts of these plant species are largely consumed by elephants.

Here, we assessed the perceptions of reserve managers and local people on the causes and the management options of the increasing elephant pressure on $B$. aethiopum populations in the PNP in Benin. The following research questions were addressed: (i) What are the perceptions of the reserve managers' and local people about the elephant pressures on $B$. aethiopum? (ii) Do professional differences of reserve managers and local people determine their perceptions of elephant pressures on $B$. aethiopum? (iii) What management actions do reserve managers feel necessary to conserve the species sustainably? Providing answers to these questions would give insights into better conservation and management of both elephants and $B$. aethiopum in the PNP. 


\section{Methods}

\section{Study Species}

B. aethiopum is widespread and common across sub-Saharan Africa (Govaerts et al., 2014) where it is a wellknown and conspicuous component of palm savannas. In Benin, B. aethiopum is found in all chorological regions (Adomou et al., 2005; Salako et al., 2015). It occurs in marshy areas and along water courses (Bayton, 2007). In the PNP, stands of $B$. aethiopum of 100-300 m width connected by small linear patches are found along the Pendjari River (Azihou, 2013) and close to natural ponds (figure 1). Four main successive life history stages are distinguishable in $B$. aethiopum (Barot and Gignoux, 1999): entire-leafed seedlings (EL-seedlings), slitted-leafed seedlings (SL-seedlings), juveniles which bear mature leaves but do not reproduce, and adults. In both seedling stages and in the younger juveniles, the terminal bud is belowground, thus defining the establishment phase (Tomlinson and Jeffrey, 1990).

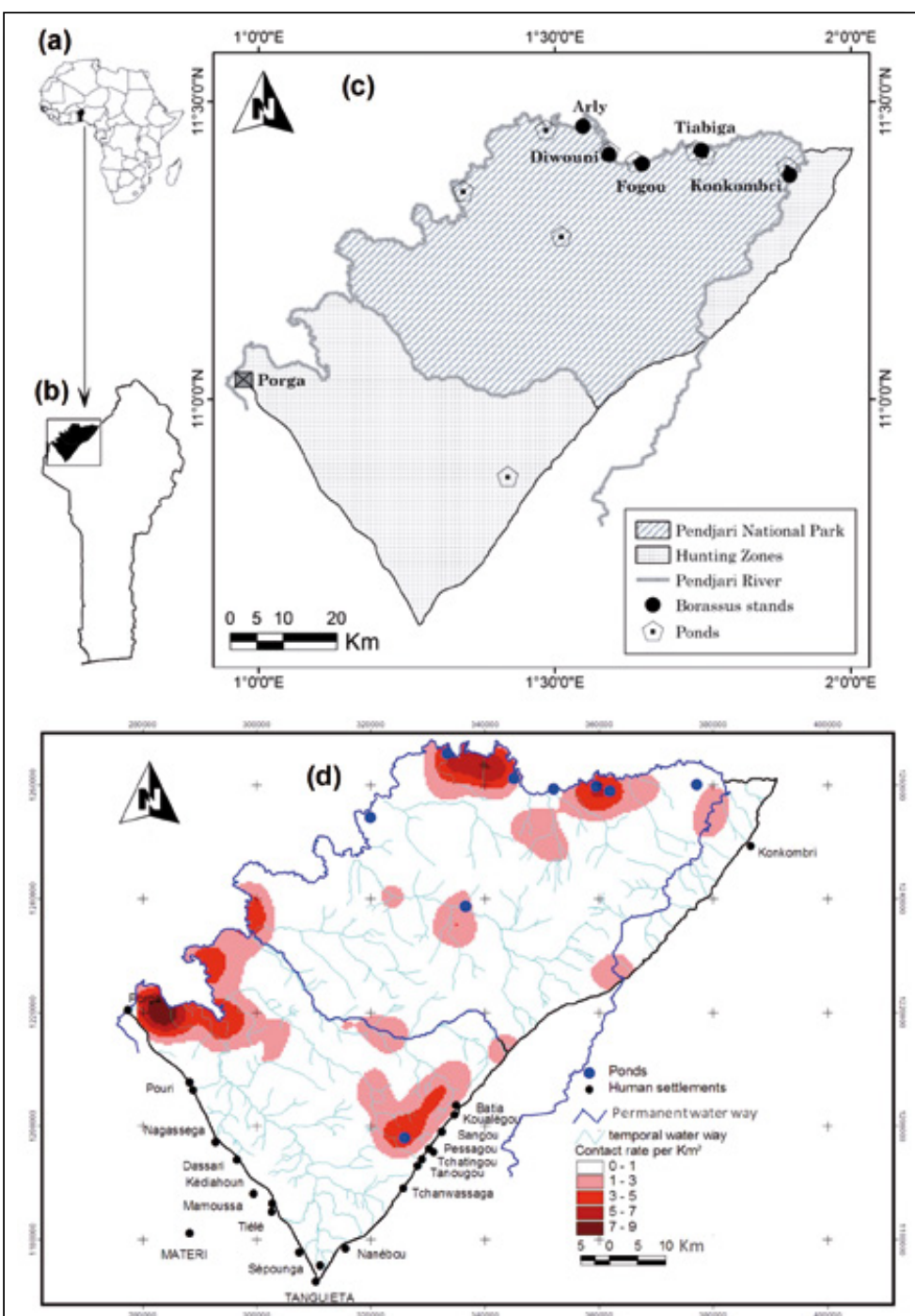

Figure 1.

Study area showing (a) the location of Benin in Africa, (b) the location of the Pendjari Biosphere Reserve in Benin, and (c) the Pendjari National Park, the ponds and location of stands of Borassus aethiopum Mart., (d) the distribution of elephants and human settlements in the Pendjari Biosphere Reserve.

\section{Study System}

The study was conducted in the Pendjari National Park (located between $10^{\circ} 40-11^{\circ} 28 \mathrm{~N}$ and $0^{\circ} 57-2^{\circ} 10 \mathrm{E}$; figure 1) which is integrally protected and hosts a high density of elephants in the Park. The study site belongs to the W-Arly-Pendjari (WAP) ecosystem, an interconnected national parks and reserves complex in West Africa.

The elephant population in the Park remained stable, from 826 individuals in 1985-1991 to 869 individuals in 2005-2010 (Bouché et al., 2011). The elephant density was estimated to approximately 0.4 individual per $\mathrm{km}^{2}$ (Kassa et al., 2014). Native vegetation in the area is dominated by woodlands, tree and shrub savannas (Sokpon et al., 2008). Annual rainfall averages 900-1,000 mm and shows a unimodal regime (from May to November) (Adomou et al., 2005). A recent study indicated significant increase in mean temperature $\left(+1^{\circ} \mathrm{C}\right.$; from 27 to $\left.28^{\circ} \mathrm{C}\right)$ and perceptible decline of the rainfall $\left(-5.5 \mathrm{~mm}_{\text {year }}{ }^{1}\right.$; from 1,220 to $\left.1,000 \mathrm{~mm}\right)$, and the number of rainy days per year (-45 days; from 115 to 70 days) between 1960 and 2008 (Gnanglè et al., 2011). Soils are mainly ferruginous. In addition to riparian people, the management of the Pendjari Biosphere Reserve involves administrators, ecoguards and Local Professional Hunters (LPHs). LPHs are people who formerly were illegal hunters, but in the frame of the participative management of the reserve, they have been reconverted after being trained for conservation.

\section{Assessment of the perceptions of reserve manager's on pressure of elephants on African fan palm populations in the Pendjari National Park}

An ethnoecological survey was conducted with the administrators, ecoguards and LPHs. These socio-professional categories were chosen because of their daily work for the management of the protected area and of their local reputations in plant-animal relationship knowledge. Administrators include the director of the Park and his assistant, the responsible for ecological censuses/monitoring and his assistant, the responsible for patrol/control of poaching activities and his assistant. The others administrators (secretary, accountant, and librarian) were not considered. Riparian people were not considered because they lived far away from location of $B$. aethiopum stands (restricted distributions) in the PNP $(\approx 90 \mathrm{~km}$; figure $1 \mathrm{c})$. In addition, they do not have access to the PNP where they could observe the interactions of elephant with B. aethiopum. Semi-structured interviews were conducted with 53 informants belonging to three socio-professional categories: administrators (6), ecoguards (17) and LPHs (30). All administrators (excluding secretary, accountant, and librarian) and ecoguards were interviewed but a sample of thirty LPHs was considered during this survey. Interviews focused on (i) changes in elephant population in the Park, (ii) causes of such changes, (iii) damage caused by elephants to $B$. aethiopum individuals, (iv) individuals affected by this damage, (v) occurrence period of damage, (vi) evolution of elephants' pressures on $B$. aethiopum, and (vii) suggestions for a sustainable conservation of both elephants and B. aethiopum. 


\section{Data analysis}

Perception was assessed through calculation of informant's consensus index. Thus, the Relative Frequency of Citation (RFC; Friedman et al., 1986) of the perceptions (elephant dynamics in the Park, causes inducing elephants' dynamics, damage caused by elephants on B. aethiopum populations, individuals affected by these damage, occurrence period of damage, evolution of elephants' pressures on $B$. aethiopum, and suggestions for a sustainable conservation of both elephants and palm trees) was calculated on the ethnoecological data. RFC is defined as the ratio of the informant number $(n)$ related to a specific perception to the total number $(\mathrm{N})$ of informants.

Then, bar charts were established both to assess consensus of informants' perceptions and variation of informants' perceptions of elephants' pressures on Borassus aethiopum following administrators, ecoguards, and LPHs. Pearson correlation in R.3.0.2 (R Development Core Team, 2014) was used to assess the concordance of the perceptions of the three socio-professional categories on the relationship between $B$. aethiopum and elephants.

\section{Results}

\section{Description of socio-professional characteristics of informants}

The ecoguards had at least 10 years of seniority while LPHs had less than 5 years for the length of service (table I). In addition, $90 \%$ of the LPHs had 10-15 years of seniority in the hunting practice before being redeployed to LPHs. $83 \%$ of administrators, and $53 \%$ of ecoguards had university and secondary level respectively while the LPHs were mostly illiterate $(67 \%)$.

\section{Perceptions of the reserve managers on the pressures of elephants on African fan palm populations}

Perceptions of reserve managers on elephant dynamics in the Park varied between socio-professional categories (figure $2 a$ ). The majority (90\%) of LPHs revealed that the elephant population has strongly increased contrary to ecoguards who essentially revealed that the increase was only slight. Some administrators perceived a stable dynamics whereas other mentioned a light increase (34\%) of the number of elephants. Concerning elephants dynamics in the PNP, correlations (table II) showed a concordance between ecoguards perceptions and those of the LPHs $(r=0.60)$ but not between administrators and ecoguards $(r=-0.39)$. Perceptions of administrators were opposed to the ones of LPHs $(r=-0.77)$.

The main cause associated with this dynamic (figure $2 \mathrm{~b}$ ) was the strong migration of the elephants (according to $87 \%$ of the LPHs, $71 \%$ of the ecoguards and $34 \%$ of the administrators) from the transboundary parks to the reserve. The correlation analysis indicated a strong concordance on the perceptions related to the causes inducing elephants' dynamics between the ecoguards and the LPHs ( $r=0.96)$ but a low concordance between those of the administrators and ecoguards $(r=0.42)$ as well as LPHs $(r=0.14)$ (table II).

Adult trees uprooting (according to $100 \%$ of the administrators and the LPHs and $89 \%$ of the ecoguards), with juveniles leaves grazing and their terminal bud removal (according to $56 \%$ of the administrators, $100 \%$ of the ecoguards and $84 \%$ of the LPHs) (photo 1 ) were reported as damages caused by the elephants to $B$. aethiopum populations (figure 2c). Adult trees' debarking (according to $0 \%$ of the administrators, $12 \%$ of the ecoguards and $14 \%$ of the LPHs) was also known as other type of damage caused by the elephants on $B$. aethiopum populations in the park. The correlations analysis (table II) showed a strong concordance between the perceptions on the damage caused by the elephants which are reported by all considered actors $(r=0.80, r=0.95$ and $r=0.94)$. Indeed, the adult trees were push down (photo 2) for their fruits (according to $67 \%$ of the administrators, $65 \%$ of the ecoguards and $50 \%$ of the LPHs), their leaves (according to $34 \%$ of the administrators, $48 \%$ of the ecoguards and $50 \%$ of the LPHs), their terminal buds (according to $17 \%$ of the administrators, $53 \%$ of the ecoguards and $34 \%$ of the LPHs) and their spongy parts $(0 \%$ of the administrators, $42 \%$ of the ecoguards and $14 \%$ of the LPHs) (photo 3). 
(a) Dynamics of elephants

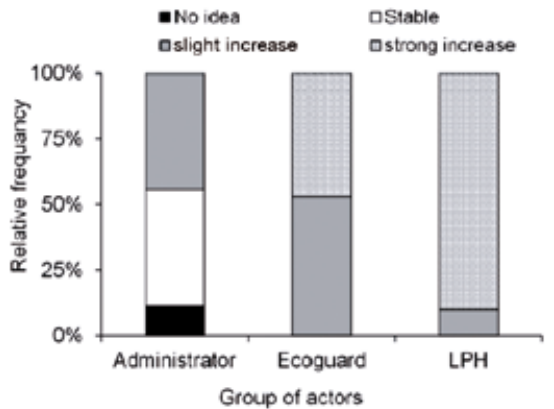

(d) Individuals affected by elephants' damage

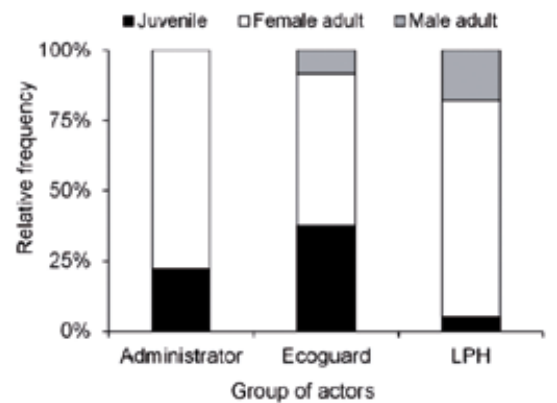

(b) Causes inducing elephants' dynamics

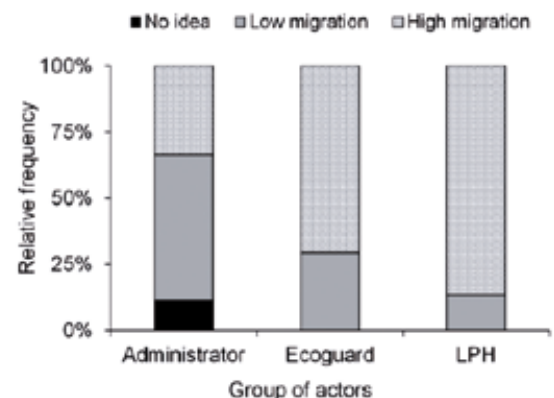

(e) Occurrence period of damage

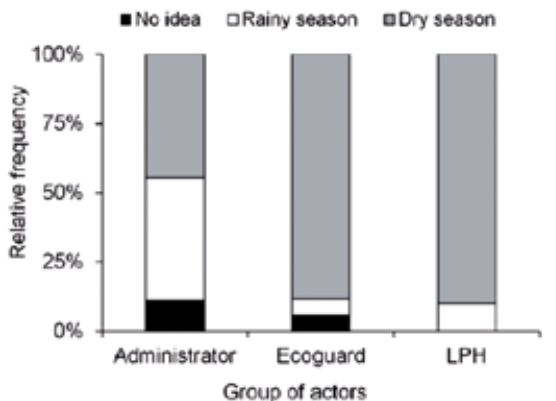

(c) Type of damage caused by elephants

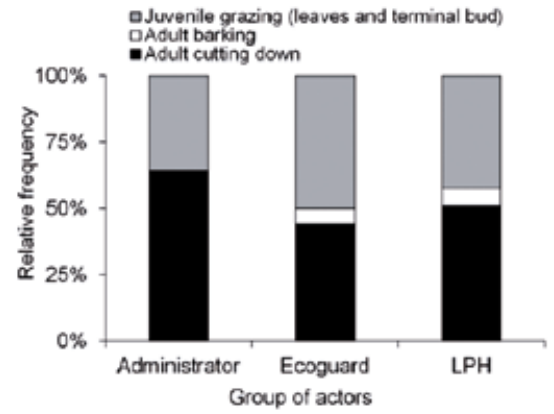

(f) Evolution of elephants' pressures on $B$. aethioptum

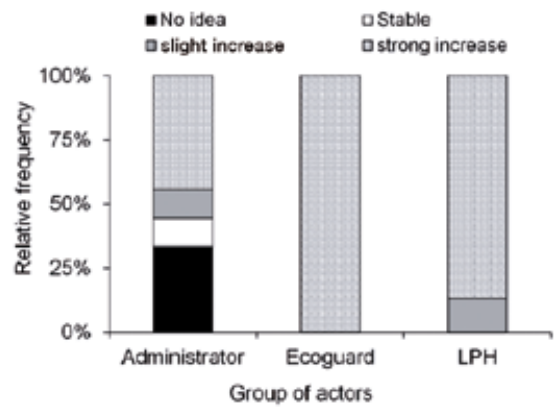

Figure 2.

Perceptions of socio-professional categories of elephants' pressures on Borassus aethiopum Mart.; LPHs - Local Professional Hunters - (a) Dynamics of elephants; (b) Causes inducing elephants' dynamics; (c) Types of damage caused by elephants; (d) Individuals affected by damages of elephants; (e) Occurrence period of elephant damages; (f) Evolution of elephants' pressures on B. aethiopum.

Table II.

Concordance between perceptions of socio-professional categories (Administrative, Adm (6); Ecoguards, Eco (17) and Local Professional Hunters, LPHs (30)): correlations ( $r$ ) between Relative Frequency of Citation (RFC) of perceptions.

\begin{tabular}{|c|c|c|c|c|c|c|}
\hline \multirow[t]{2}{*}{ Perceptions } & \multicolumn{2}{|c|}{ Eco*Adm } & \multicolumn{2}{|c|}{ Eco*LPHs } & \multicolumn{2}{|c|}{ AdmLPHs } \\
\hline & $\mathbf{r}$ & Prob. & $\mathbf{r}$ & Prob. & r & Prob. \\
\hline Dynamics of elephants & -0.39 & 0.607 & 0.60 & 0.396 & -0.77 & 0.230 \\
\hline Causes inducing elephants dynamics & 0.42 & 0.728 & 0.96 & 0.178 & 0.14 & 0.907 \\
\hline Types of damage caused by elephants & 0.80 & 0.412 & 0.95 & 0.186 & 0.94 & 0.217 \\
\hline Individuals affected by these damage & 0.99 & 0.100 & 0.66 & 0.538 & 0.77 & 0.440 \\
\hline Occurrence period of damage & 0.87 & 0.333 & 0.99 & 0.068 & 0.91 & 0.269 \\
\hline $\begin{array}{l}\text { Evolution of elephants' pressures } \\
\text { on Borassus aethiopum Mart. }\end{array}$ & 0.87 & 0.333 & 0.99 & 0.008 & 0.93 & 0.242 \\
\hline $\begin{array}{l}\text { Suggestions for limiting elephants' } \\
\text { pressures on Borassus aethiopum Mart. }\end{array}$ & 0.98 & 0.016 & 0.96 & 0.009 & 0.99 & 0.001 \\
\hline
\end{tabular}

Female trees (according to $67 \%$ of the administrators, $77 \%$ of the ecoguards and $100 \%$ of the LPHs) and to a lesser extent the juveniles (according to $34 \%$ of the administrators, $53 \%$ of the ecoguards and $7 \%$ of the LPHs) constitute the most affected life stages and consequently, the most threatened (figure 2d). There is also a strong concordance between the perceptions on the most affected individuals $(r=0.99, r=0.66$ and $r=0.77)$ which were reported by the various socio-professional groups (table II). 
The dry season was the main period of the damage occurrence according to the majority of the ecoguards and the LPHs ( $89 \%$ and $90 \%$ respectively) while the administrators are shared between dry and rainy seasons (figure 2e). Besides, the pressure of elephant on B. aethiopum was in strong increase according to the majority of administrators, ecoguards and LPHs (50\%, 100\% and $87 \%$ respectively) (figure 2f). The perceptions over the period of the damage occurrence and the trend of the elephants' pressure on B. aethiopum were concordant among the categories of informants $(r=0.87, r=0.99$ and $r=0.91)$.

\section{Management options to reduce elephants' pressures on African fan palm}

To reduce the pressure of elephants on $B$. aethiopum individuals, the definition of the elephants' hunting quota (18\% of the ecoguards and $4 \%$ of the LPHs), the multiplication of water sources (12\% of the ecoguards) and the supervision of the park borders $(6 \%$ of the ecoguards and $4 \%$ of the LPHs) were suggested by the actors. However, most of them $(67 \%$ of the administrators, $65 \%$ of the ecoguards and $80 \%$ of the LPHs) suggested a non-intervention or a laissez-faire approach.

A strong concordance of the perceptions $(r=0.98, r=0.96$ and $r=0.99$ for Eco*Adm, Eco*LPHs, and Adm*LPHs respectively) on the management options of the elephants' pressures was noted between the various actors perceptions.

\section{Discussion}

This study investigated how reserve managers and local people understand the plant-animal relationship involving the palm species $B$. aethiopum with which elephants interact in the Pendjari National Park. Our results illustrate how information on local perceptions can provide insight on decision-making processes for local resource conservation and inform locally appropriate sustainable management plans.

\section{Local perceptions of elephants' pressure on African fan palm populations}

Our interviews revealed that the reserve managers have detailed knowledge of the causes and the management options of the increasing pressures of the elephants on B. aethiopum populations in the PNP. As a result, the three categories of actors globally agreed on the causes inducing the elephant dynamics, the damages caused by elephants on $B$. aethiopum populations, the individuals most affected by those damages, the seasons of the damages, the trend of the elephant pressures on B. aethiopum and the suggestions for the reduction of these pressures. This global trend likely comes from the fact that the professional differences between the informants are not very high. Indeed, all the

actors work in the PNP and therefore, they had at that time access to the PNP where they would have been in touch with the elephants and $B$. aethiopum populations. The strong concordance between the perceptions of the ecoguards and those of the LPHs is likely because they are the most involved in the field activities (mainly censuses and monitoring). Despite that ecoguards and LPHs reported a high increase of the number of elephants and the administrators reported only a slight increase, all agree on an increase of the elephant density in the PNP. This consensus refutes the prediction that the professional differences between informants drive no concordance of their perceptions (Müller-Schwarze, 2006) and suggest that when the working environment is the same, the perceptions of informants are similar if the studied phenomenon takes place in this environment. According to informants, the increase of the elephant density results in the strong migration of the elephants from the transboundary parks. Tehou (2002) observed very large fluctuations in the number of elephant and had also suggested a strong migration of elephants towards the PNP. This strong migration was associated with the outbreak of poaching in these parks and would be at the origin of the increasing pressures on $B$. aethiopum and other species such as $A$. digitata in the PNP (Kassa et al., 2014). Apart from poaching, other factors such as climate change could also explain the strong migration of the elephants towards the PNP. Indeed, the increasing aridification in the Sahel and the dry sudanian region would have led to the rarefaction of water resources, on which the elephants depend (O'Connor et al., 2007). As a result, the PNP where many natural and 


\section{Appropriate management options to reduce pressure of elephant on African fan palm}

artificial ponds are found containing water even in dry season appears to be a safe refuge. Loarie et al. (2009) showed that water resources are key drivers of elephant movements. Human-elephant conflicts marked by increasing encroachment of elephant natural habitats (O'Connor et al., 2007) may also be an additional reason for the reported increasing elephants' pressure on $B$. aethiopum. Moreover, informants believe that the pressures of elephants on $B$. aethiopum are going to become more marked if the poaching pressures do not decrease in the other parks, thus suggesting that regional efforts are necessary to shield certain plants of the strong pressure of the elephants. Because the PNP is not fenced and belongs to a regional network of protected areas (W-A-P), elephants migrate freely across countries borders within the network, and as such, a regional management plan of elephant populations will be more effective for addressing elephant-plant relationships (O'Connor et al., 2007). The reported damages of elephants to $B$. aethiopum trees are also congruent with findings of Salako et al. (2016), indicating a matching between perceptions of informants and the actual observed damages.
Suggestions made by the informants for the sustainable management of both elephant and $B$. aethiopum are already known practices, especially in regard elephant populations (Balfour et al., 2007). However, the global trend (majority of the informants) is for a non-intervention. Indeed, non-intervention option is the most common management option (Balfour et al., 2007), even if it is not strictly a management action and the intention is not to reduce the densities of the elephants but rather to allow a natural equilibrium, as when there is a collapse led by resources (Balfour et al., 2007). For instance, this approach has been used in Kenya. In other countries such as Botswana, there has been the intent to intervene but logistics, lack of capacity, sensitivity to the opinions of those with anti-culling viewpoints, and lack of suitable destinations for translocated animals have led managers to do nothing to control elephant numbers (Balfour et al., 2007). As a result, non-intervention has been the default management option although it is not the stated policy. Although this option favors a natural regulation of this imbalance pledge of a stability and an ecosystem resilience (Ogutu and Owen-Smith, 2003) as well as the skid

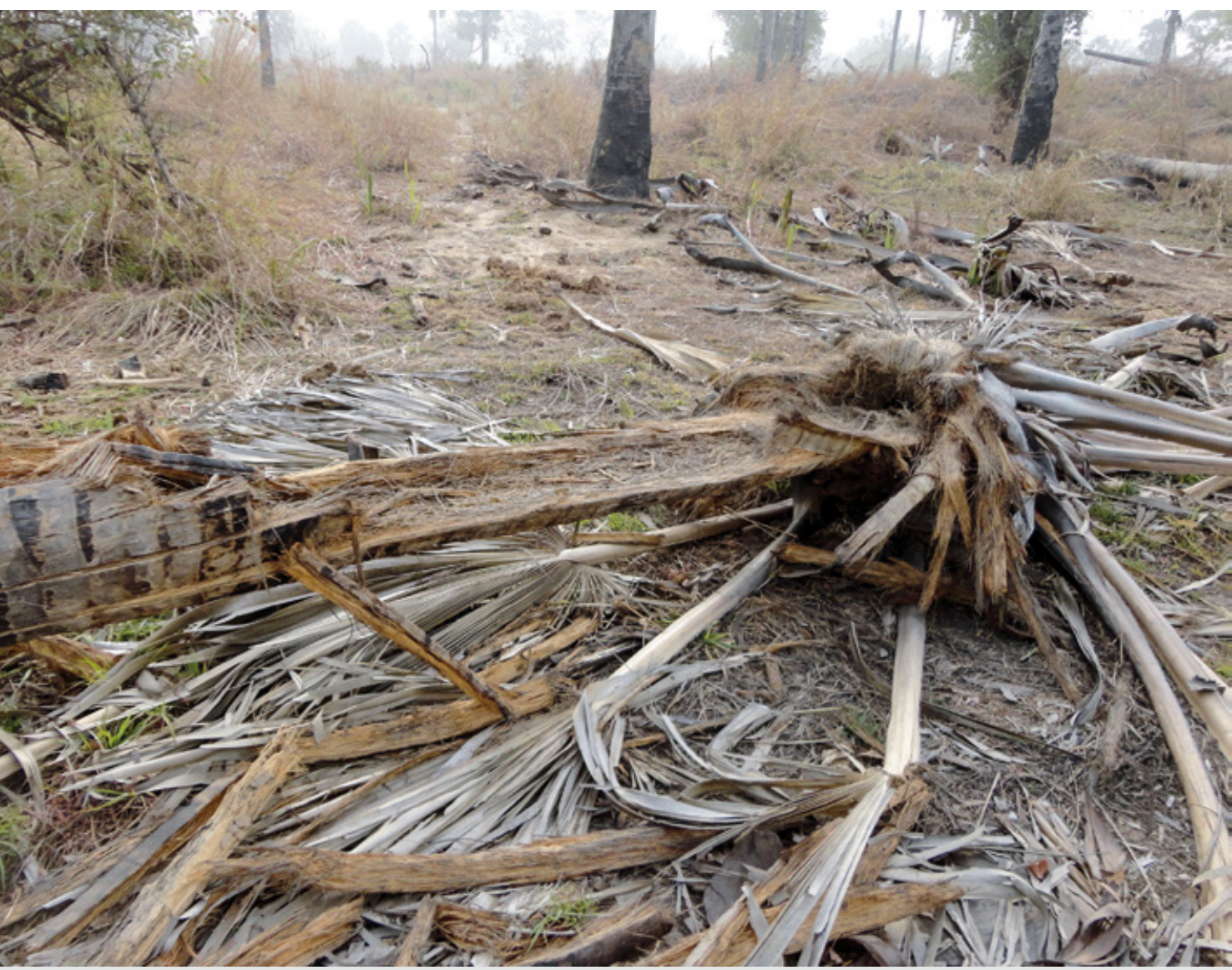

Photo 3.

An uprooted B. aethiopum tree which central part has been eaten by elephants.

Photo V.K. Salako. avoidance which could ensue from direct anthropogenic actions on the ecological balance (du Toit et al., 2003), it has some drawbacks (Balfour et al., 2007). Thus, pursuing this management option through the reserves can lead to not only increasing soil erosion which occurs in areas where vegetation has been removed (e.g. in Chobe National Park, Botswana) but also at possible loss of other water-dependent species during dry spells due to elephants totally dominating water sources (Lugoloobi, 1993). Similarly, the extensive habitat modification can be observed due to conversion of woodland to shrubland or grassland with change in structure and composition of the canopy of trees, and by extension in survival of recruitment (Cumming et al., 1997). Consequently, the persistence of elephant damage on vegetation can lead to a local extirpation of the species 
under increasing threats (Lombard et al., 2001) but also at the declining of the others animals and plant species that strongly depend on the target plant (Cumming et al., 1997). Managers can also use others management options, including translocation, contraception and source-sink migration regarding a local overabundance of elephant population (Le Bel et al., 2013). Thus, for reducing elephant damage on $B$. aethiopum in the PNP, the reserve managers could experiment these management options which still remain technically challenging.

Our findings revealed increasing elephant damage on B. aethiopum in the PNP particularly during the dry season. Elephants are well known to mainly affect vegetation structure during the dry season, when they are predominantly browsers (Owen-Smith, 1988), and these effects increase with increasing elephant densities (Ben-Shahar, 1996). In addition, previous work has reported that the effects remain stronger in the vicinity of waterholes (de Beer et al., 2006), where aggregation of elephants occurs during the dry season (Stokke and du Toit, 2002). For instance, distribution and abundance of elephants during dry season are largely influenced by surface-water availability within Hwange National Park in Zimbabwe. Thus, the surface-water management may allow balancing elephant population size and elephant impact on ecosystems (Chamaillé-Jammes et al., 2007). Therefore, we urge managers to consider manipulation of waterpoints as other management tool for reducing elephant pressures on B. aethiopum in PNP.

\section{Implications for sustainable management of the Pendjari National Park}

Our findings suggest that LEK provides a useful estimate of the condition of vegetation within the protected areas when facing shortage of empirical data to inform decisions about their management. Indeed, the scarcity and the high cost of classical ecological censuses/monitoring means that other sources of information are needed to complement empirical evidence for conservation decisions. By regularly interacting with their local environment, reserve managers may generate LEK that can be used to inform management decisions. For instance, LEK is considered particularly useful for environmental management decisions (Davis and Ruddle, 2010) and has been used to provide information about the presence or abundance of species (Anadón et al., 2009), population trends (Gilchrist et al., 2005), and sizeclass distributions (Aswani and Hamilton, 2004). It has been shown to be a cost-effective source of ecological data (Anadón et al., 2009), particularly when conventional ecological research is too expensive or cannot be conducted within the necessary time frame (Stave et al., 2007). However, the essential issue of the reliability of LEK as a source of evidence to guide protected area management still remains debating because it can be susceptible to a range of biases (Plous, 1993). For example, the distortion of manager's perceptions of on-ground conditions based on information derived from personal knowledge could lead to poor conservation outcomes (Sutherland, 2006).
Nevertheless, this study provides an important first step in understanding managers' perception as a source of LEK, which shows that when the working environment is the same, the perceptions of informants are similar if the studied phenomenon takes place in this environment. The findings suggest that accounting for perceptions of local people in regards elephant-plant interactions has an added value to the understanding of such interactions and should therefore use to complement direct field studies/observations. Still, there is a considerable gap in understanding how informants build perceptions and the circumstances and personal attributes that contribute to building reliable knowledge for elephant-plant interactions. Given the potential value of such a source of ecological information to guide protected area management, we encourage more research to help management agencies understand how to enable managers to build a strong understanding of the conditions in their reserves and to guide the use of this information for management decisions.

\section{Conclusion}

In African savannas, elephants (Loxodonta africana) are known to be major agents of adult tree mortality, impacting trees through browsing, bark stripping and uprooting. Understanding drivers and consequences of such interaction is pivotal for sustainable management. When facing shortage of empirical data to inform decisions about their management, Local Ecological Knowledge (LEK) could provide a useful estimate of the condition of vegetation within the protected areas. Despite professional differences, consensual and concordant opinions were noted among administrators, ecoguards and LPHs on the relationship between $B$. aethiopum and elephants. Informants reported a high increase of the number of elephants in the PNP, which they attributed to their high migration from transboundary parks due to high poaching activities. This has resulted in high pressure on tree species of which $B$. aethiopum in dry season. The study highlights the importance to account for LEK when studying elephant-plant interactions in protected areas, especially in providing primary information for deepen on-ground investigations. We suggest that managers consider manipulation of waterpoints as well as working for a regional approach to secure elephants (to low poaching) in the complex WAP (W-Arly-Pendjari) and other neighboring reserves. This is expected to limit high migration of elephants from the transboundary parks to the PNP and solve problems of locally high elephant abundances, and consequently reduce elephant pressure on a narrow set of plants. Expanding the research to other plant species facing such pressures as well as their local extirpation risk would provide an added value.

\section{Acknowledgements}

This study was supported by the Belgium CUD Scholarship attributed to JSHH and the International Foundation for Science Research Grant No D/5448-1 attributed to VKS. We are grateful to the PNP authorities, ecoguards and Local Professional Hunters who freely shared their experiences and knowledge. We also thank Apollinaire Nabigou and Benoît Gnarigo for invaluable help in the field. 


\section{References}

Adomou C. A., 2005. Vegetation Patterns and Environmental gradients in Benin: Implications for biogeography and conservation. PhD Thesis, Wageningen University, 133 p.

Adomou C. A., Agbani O. P., Sinsin B., 2011. Plants. In: Nature Conservation in West Africa: Red List for Benin, Eds Neuenschwander P., Sinsin B., Goergen G., International Institute of Tropical Agriculture, Ibadan, p. 21-46.

Agyarko K., Samuel K. J., Russel B., Tony K. M., Antuong I. S., 2014. Views of Preventing Borassus aethiopum from Extinction among Four Communities in Ghana. Journal of Natural Science Research, 4 (2): 83-89.

Anadón J. D., Giménez A., Ballestar R., Pérez I., 2009. Evaluation of local ecological knowledge as a method for collecting extensive data on animal abundance. Conservation Biology, 23: 617-625.

Arbonnier M., 2004. Trees, shrubs and lianas of West African dry zones. Versailles, France, Éditions Quæ, 573 p.

Aswani S., Hamilton R. J., 2004. Integrating indigenous ecological knowledge and customary sea tenure with marine and social science for conservation of bumphead parrotfish (Bolbometopon muricatum) in the Roviana Lagoon, Solomon Islands. Environmental Conservation, 31: 69-83.

Azihou A. F., 2013. Ecology of isolated trees in tropical savannas: modelling of plant species distribution and colonization of new habitats through long-distance dispersal and facilitation. PhD Thesis, University of Abomey-Calavi, 162 p.

Balfour D., Dublin H. T., Fennessy J., Gibson D., Niskanen L., Whyte I. J., 2007. Examen des options pour le contrôle des impacts de la surabondance locale des éléphants africains. Gland, Suisse, UICN, 80 p.

Barnes R. F. W., 1983. The elephant problem in Ruaha National Park, Tanzania. Biological Conservation, 26: 127-148.

Barot S., Gignoux J., 1999. Population Structure and Life Cycle of Borassus aethiopum Mart.: Evidence of Early Senescence in a Palm Tree. Biotropica, 31: 439-448.

Bayton R. P., 2007. A Revision of Borassus L. (Arecaceae). Kew Bulletin, 62: 561-585.

Ben-Shahar R., 1996. Woodland dynamics under the influence of elephants and fire in northern Botswana. Vegetatio, 123: 153-163.

Botes A., McGeoch M. A., Van Rensburg B. J., 2006. Elephant- and human-induced changes to dung beetle (Coleoptera: Scarabaeidae) assemblages in the Maputaland Centre of Endemism. Biological Conservation, 130: 573-583.

Bouché P. H., Douglas-Hamilton I., Wittemyer G., Nianogo A. J., Doucet J. L., Lejeune P. H., et al., 2011. Will elephants soon disappear from West African savannas? PLoS One, 6 (6): e20619.
Chamaillé-Jammes S., Valeix M., Fritz H., 2007. Managing heterogeneity in elephant distribution: interactions between elephant population density and surface-water availability. Journal of Applied Ecology, 44: 625-633.

Cook C. N., Hockings M., 2011. Opportunities for improving the rigor of management effectiveness evaluations in protected areas. Conservation Letters, 4: 372-382.

Cook C. N., Hockings M., Carter R. W., 2010. Conservation in the dark? The information used to support management decisions. Frontiers in Ecology and the Environment, 8: 181-186.

Cumming D. H. M., Fenton M. B., Rautenback I. L., Taylor R. D., Cumming G. S., Cumming M. S., et al., 1997. Elephants, woodlands and biodiversity in southern Africa. South African Journal of Science, 93: 231-236.

Davis A., Ruddle K., 2010. Constructing confidence: rational skepticism and systematic enquiry in local ecological knowledge research. Ecological Applications, 20: 880-894.

de Beer Y., Kilian W., Versfeld W., van Aarde R. J., 2006. Elephants and low rainfall alter woody vegetation in Etosha National Park, Namibia. Journal of Arid Environments, 64: 412-421.

du Toit J. T., Biggs H. C., Rogers K. H., 2003. The Kruger experience: ecology and management of savanna heterogeneity. Washington, DC, Island Press, 518 p.

Fraser D. J., Coon T., Prince M. R., Dion R., Bernatchez L., 2006. Integrating Traditional and Evolutionary Knowledge in Biodiversity Conservation: A Population Level Case Study. Ecology and Society, 11: 4.

Friedman J., Yaniv Z., Dafni A., Palewicth D., 1986. A preliminary classification of the healing potential of medicinal plants, based on a rational analysis of an ethnopharmacological field survey among Bedouins in the Negev Desert, Israel. Journal of Ethnopharmacology, 16: 275-287.

Fritz H., Duncan P., Gordon I. J., Illius A. W., 2002. Megaherbivores influence trophic guilds structure in African ungulate communities. Oecologia, 131: 620-625.

Fullman T. J., Bunting E. L., 2014. Analyzing Vegetation Change in an Elephant-Impacted Landscape Using the Moving Standard Deviation Index. Land, 3: 74-104.

Giffard P. L., 1967. Le palmier rônier : Borassus aethiopum Mart. Bois et Forêts des Tropiques, $116: 3-13$. http://bft. cirad.fr/cd/BFT 116 3-13.pdf

Gilchrist G., Mallory M., Merkel F., 2005. Can local ecological knowledge contribute to wildlife management? Case studies of migratory birds. Ecology and Society, 10 (1): 20.

Gillson L., Lindsay K., 2003. Ivory and ecology-changing perspectives on elephant management and the international trade in ivory. Environmental Science and Policy, 6: 411-41.

Gnanglè C. P., Glèlè Kakaï R., Assogbadjo A. E., Vodounon S., Yabi J., Sokpon N., 2011. Tendances climatiques passées, modélisation, perceptions et adaptations locales au Bénin. Climatologie, $8: 27-40$. 
Govaerts R., Dransfield J., Zona S., Hodel D. R., Henderson A., 2014. World Checklist of Arecaceae. Facilitated by the Royal Botanic Gardens Kew, UK. http://apps.kew.org/wcsp Karimi R. R., 2009. An Assessment of Perceived Crop Damage in a Tanzanian Village Impacted by Human-Elephant Conflict and an Investigation of Deterrent Properties of African Elephant (Loxodonta Africana) Exudates Using Bioassays. MS Thesis, Georgia Southern University, 90 p.

Kassa B. D., Fandohan B., Azihou A. F., Assogbadjo A. E., Oduor A. M. O., Kidjo F. C., et al., 2014. Survey of Loxodonta africana (Elephantidae)-caused bark injury on Adansonia digitata (Malvaceae) within Pendjari Biosphere Reserve, Benin. African Journal of Ecology, 52: 385-394.

Le Bel S., Stansfield F., La Grange M., Taylor R., 2013. Managing local overabundance of elephants through game meat supply, the case of Savé Valley Conservancy in Zimbabwe. South African Journal of Wildlife Research, 43 (2): 103-119.

Lewis D. M., 1986. Disturbance effects on elephant feeding: evidence for compression in Luangwa Valley, Zambia. African Journal of Ecology, 24: 227-241.

Loarie S. R., Aarde R. J. V., Pimm S. L., 2009. Fences and artificial water affect African savannah elephant movement patterns. Biological Conservation, 142: 3086-3098.

Lombard A. T., Johnson F. C., Cowling R. M., Pressey L. R., 2001. Protecting plants from elephants: botanical reserve scenarios within the Addo Elephant National Park, South Africa. Biological Conservation, 102: 191-203.

Lugoloobi W., 1993. A preliminary report on the vegetation status and elephant utilisation along the Chobe River front in Chobe National Park. Botswana, Department of Wildlife and National Parks.

Mollet M., Herzog F., Behi Y. E. N., Farah Z., 2000. Sustainable exploitation of Borassus aethiopum, Elaeis guineensis and Raphia hookeri for the Extraction of Palm Wine in Côte d'Ivoire. Environment, Development and Sustainability, 2: 45-59.

Morrison T. A., Holdo R. M., Anderson T. M., 2016. Elephant damage, not fire or rainfall, explains mortality of overstorey trees in Serengeti. Journal of Ecology, 104: 409-418.

Mosugelo D. K., Moe S. R., Ringrose S., Nellemann C., 2002. Vegetation changes during a 36-year period in northern Chobe National Park, Botswana. African Journal of Ecology, 40: 232-240.

Müller-Schwarze N. K., 2006. Antes and HoyDía: Plant Knowledge and Categorization as Adaptations to Life in Panama in the Twenty-first Century. Economic Botany, 60: 321-334.

Mwalyosi R. B. B., 1985. Decline of Acacia tortilis in Lake Manyara National Park, Tanzania. African Journal of Ecology, 25: 51-53.

O'Connor T. G., Goodman P. S., Clegg B., 2007. A functional hypothesis of the threat of local extirpation of woody plant species by elephant in Africa. Biological Conservation, 136: 329-345.
Ogutu J., Owen-Smith R. N., 2003. ENSO, rainfall and temperature influences on extreme population declines among African savanna ungulates. Ecology Letters, 6: 412-419.

Owen-Smith R. N., 1988. Megaherbivores: the Influence of Very Large Body Size on Ecology. Cambridge, UK, Cambridge University Press, 369 p.

Plous S., 1993. The psychology of judgment and decision making. New York, USA, McGraw-Hill Education, 320 p.

R Core Team, 2014. R: A language and environment for statistical computing. Vienna, Austria, R Foundation for Statistical Computing. http://www.R-project.org/

Salako V. K., Assogbadjo A. E., Adomou A. C., Agbangla C., Glèlè Kakaï R. L., 2015. Latitudinal distribution, co-occurring tree species and structural diversity of the threatened palm Borassus aethiopum (Arecaceae) in Benin, West Africa. Plant Ecology and Evolution, 148: 335-349.

Salako V. K., Azihou A. F., Assogbadjo A. E., Houéhanou T. D., Kassa B. D., Glèlè Kakaï R. L., 2016. Elephant-induced damage drives spatial isolation of the dioecious palm Borassus aethiopum Mart. (Arecaceae) in the Pendjari National Park, Benin. African Journal of Ecology, 54 (1): 9-19.

Sokpon N., Affoukou M., Amahowe I., Gandji L., Gnonlonfin L., Sossou B., 2008. Dynamique spatio-temporelle des formations végétales du Complexe Parc National de la Pendjari, Zones cynégétiques de la Pendjari et de l'Atacora. CENAGREF, Benin.

Stave J., Oba G., Nordal I., Stenseth N. C., 2007. Traditional ecological knowledge of a riverine forest in Turkana, Kenya: implications for research and management. Biodiversity and Conservation, 16: 1471-1489.

Stokke S., du Toit J. T., 2002. Sexual segregation in habitat use by elephants in Chobe National Park, Botswana. African Journal of Ecology, 40: 360-371.

Sutherland W. J., 2006. Predicting the ecological consequences of environmental change: a review of the methods. Journal of Applied Ecology, 43: 599-616.

Tehou A. C., 2002. Les éléphants Loxodonta africana dans la Réserve de Biosphère de la Pendjari, Nord-Ouest République du Bénin : abondance, densité et répartition spatiale. Pachyderm, 33: 64-68.

Tomlinson P. B., Jeffrey E. C., 1990. The structural biology of palms. Oxford, UK, Clarendon Press.

Western D., Maitumo D., 2004. Woodland loss and restoration in a savanna park: a 20-year experiment. African Journal of Ecology, 42: 111-121.

Whyte I. J., Biggs H. C., Gaylard A., Braack L. E. O., 1999. A new policy for the management of the Kruger National Park's elephant population. Koedoe, 42: 111-132. 